\title{
Negative effects of an autogenic ecosystem engineer: interactions between coralline turf and an ephemeral green alga
}

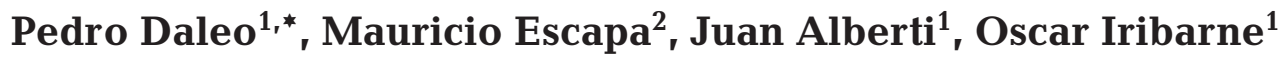 \\ ${ }^{1}$ Laboratorio de Ecología, Departamento de Biología (FCEyN), Universidad Nacional de Mar del Plata, CC 573 Correo \\ Central, B7600WAG, Mar del Plata, Argentina \\ ${ }^{2}$ Instituto Argentino de Oceanografía (IADO), CC 804 Correo Central, 8000 Bahía Blanca, Argentina
}

\begin{abstract}
Organisms that physically modify habitat by their own presence can either positively or negatively affect other species. The direction of the effect depends on how physical variables are modified and the response of species to these variables. In this study, we investigated the interactions between an intertidal turf-forming algae Corallina officinalis and the common sea lettuce Ulva lactuca. Field sampling showed that $U$. lactuca coverage and individual dry weight was less when coexisting with coralline turf than when growing alone at the same tidal height. However, there was no difference in mat density between both growing conditions. Transplant experiments showed that coralline turfs affect the biomass of U. lactuca and that this effect is related to turf/desiccation interaction. Surface was more irregular in zones with turf than in zones without turf, and transplant experiments showed that the effect of $C$. officinalis surface mimics on $U$. lactuca was similar to the effect of real turf. This example demonstrated that species' response to habitat modification by autogenic ecosystem engineers such as coralline algae is not necessarily positive.
\end{abstract}

KEY WORDS: Corallina officinalis $\cdot$ Coralline algae $\cdot$ Desiccation $\cdot$ Ecosystem engineering $\cdot$ Habitat modification $\cdot$ Intertidal $\cdot$ Turf $\cdot$ Ulva lactuca

\section{INTRODUCTION}

Terrestrial vegetated habitats, rocky shores, coral reefs, salt marshes and many other habitats are dominated by organisms that, by their own presence, modify the physical conditions of the environment (Jones et al. 1994, Callaway et al. 2002, Bruno et al. 2003). These organisms that by means of their own structures modify the environment are named autogenic ecosystem engineers (sensu Jones et al. 1994). The 3D structure created by them can have profound effects on community structure (Gilinsky 1984, Hacker \& Steneck 1990, Downes et al. 1998) and, in general have positive effect on species abundances and species richness (e.g. MacArthur \& MacArthur 1961, Murdoch et al. 1972, Gilinsky 1984, Dean \& Connell 1987, Crooks 2002, Fogel et al. 2004). Nevertheless, the response of indi- vidual species to 3D structures created by autogenic engineers may not be necessarily positive because organisms do not respond to the physical structure per se, but to some resource associated with it (Jones et al. 1997, Gutiérrez \& Iribarne 2004).

Turf-forming coralline algae are known to create physical structures (Kelaher 2002, 2003) that ameliorate desiccation stress and provide refuge from predators, positively affecting many organisms (Kelaher et al. 2003) and creating extremely rich macrofaunal assemblages (Kelaher et al. 2004). Corallines can also generate hard surface suitable for the attachment of fast growing fleshly algae and decrease desiccation, allowing settlings to survive (Johnson \& Mann 1986). Nevertheless, it is reasonable to expect that while desiccation stress is ameliorated inside the coralline matrix it may not be the same above it. Thus, the effect 
of coralline algae on epiphytes would not necessarily be positive.

In this study, we focused on the host-epiphyte interactions between the sea lettuce Ulva lactuca Linnaeus 1753 and the turf-forming algae Corallina officinalis Linnaeus 1758. C. officinalis is a widely distributed species that is dominant in many intertidal habitats (see Kelaher et al. 2004) including the coast of the Argentinean Patagonia (Helbling et al. 2004). Our previous observations suggested that when $U$. lactuca is found growing above $C$. officinalis patches, its cover is less than when growing alone. This appears to be due to smaller mats, not to reduced density. Furthermore, $U$. lactuca living inside $C$. officinalis patches appears to have damaged fronds and to be more dehydrated during low tide (P. Daleo pers. obs.). This may indicate that the amelioration of desiccation stress produced by coralline turfs, which positively affect epifaunal organisms, is negatively correlated with increasing size of associated organisms such as macroalgae. Thus, given that the response of $U$. lactuca may depend on the modification of resources (i.e. humidity) but not on the structure per se (see Gutiérrez \& Iribarne 2004), we hypothesized that $C$. officinalis may negatively affect $U$. lactuca by modifying surface topography and increasing desiccation stress.

\section{MATERIALS AND METHODS}

Study site. Field experiments and observations were conducted at San Antonio Bay (Argentina: $40^{\circ} 45^{\prime} \mathrm{S}$, $65^{\circ} 55^{\prime} \mathrm{W}$ ) from September 2003 to March 2004. This is an $80 \mathrm{~km}^{2}$ embayment affected by up to $9 \mathrm{~m}$ semidiurnal tides. The intertidal zone is characterized by sandy pebble flats at lower tidal elevations (i.e. 0 to $4 \mathrm{~m}$ above the mean low tide level [hereafter MLTL]), and salt marshes dominated by the smooth cordgrass Spartina alterniflora at higher tidal elevations (i.e. 4 to $10 \mathrm{~m}$ above MLTL). This site is an important biodiversity reserve in northern Patagonia, and is part of the Western Hemisphere Shorebird Reserve Network International (WHSRN) due to its importance as a stopover site for neotropical migratory shorebirds (Morrison \& Ross 1989). At this site, Corallina officinalis grows to form patches interspersed with zones without turf (P. Daleo pers. obs.).

Patterns of distribution of Ulva lactuca. To evaluate the hypothesis that the vertical distribution of Ulva lactuca is different in zones with and without Corallina officinalis, transects across the intertidal and parallel to the intertidal slope were established in zones with and without $C$. officinalis (10 zones of each type, 1 transect per zone). Eleven square sampling plots $\left(0.5 \mathrm{~m}^{2}\right)$ were established along each transect at height intervals of
$0.3 \mathrm{~m}$, and the cover of $U$. lactuca was visually estimated (10\% scale; see Dethier et al. 1993) at each of these plots. A factorial ANOVA with 3 factors - Habitat type (fixed, 2 levels); Transect (random, 10 levels and nested within Habitat) and Tidal level (fixed, 11 levels, crossed with Habitat and Transect [Habitat]) — was used to evaluate the relationship between presence/ absence of $C$. officinalis, location along the intertidal slope, and the interaction between both factors on $U$. lactuca cover (see Underwood 1997). Tukey post hoc comparisons (Underwood 1997) were conducted on the significant interaction term in order to evaluate differences in $U$. lactuca cover between zones with and without $C$. officinalis at each specific tidal height.

To evaluate if Ulva lactuca density varies due to the presence of Corallina officinalis, U. lactuca mats were counted in zones covered and uncovered by C. officinalis located $1 \mathrm{~m}$ height above MLTL. In each zone 15 square plots ( $0.5 \mathrm{~m}$ side) were established. The $H_{0}$ of no difference in $U$. lactuca density between both zones was analyzed with a $t$-test (Zar 1999).

To evaluate if the biomass of individual Ulva lactuca mats differ between zones with and without Corallina officinalis, individual mats of U. lactuca were randomly sampled at $1 \mathrm{~m}$ height above MLTL in zones covered by $C$. officinalis and bare substrate ( $\mathrm{n}=23$ per zone). Ulva lactuca mats were dried $\left(70^{\circ} \mathrm{C}\right.$ during $\left.48 \mathrm{~h}\right)$ and weighed (precision $0.001 \mathrm{~g}$ ). The $H_{0}$ of no difference in $U$. lactuca dry weight between zones covered by C. officinalis and bare substrate was evaluated with a $t$-test (Zar 1999).

Effect of Corallina officinalis on the biomass of individual Ulva lactuca mats. A transplant experiment was performed to evaluate the hypothesis that Corallina officinalis affects the biomass of Ulva lactuca. The experiment consisted of the following treatments (9 replicates each): (1) U. lactuca from zones without C. officinalis transplanted to zones with C. officinalis (transplanted), (2) U. lactuca from zones with C. officinalis transplanted to zones without $C$. officinalis (transplanted), (3) U. lactuca from zones without $C$. officinalis translocated to zones without $C$. officinalis (translocated; control for manipulation and relocation effects), (4) U. lactuca from zones with $C$. officinalis translocated to zones with $C$. officinalis (translocated; control for manipulation and relocation effects), (5) U. lactuca from zones without $C$. officinalis not transplanted (unmanipulated; control), and (6) U. lactuca from zones with $C$. officinalis not transplanted (unmanipulated; control). Ulva lactuca mats were transplanted by relocating individual mats together with $10 \times 10 \mathrm{~mm}$ portion of $C$. officinalis turf or the stone (approximately $10 \times 10 \times$ $10 \mathrm{~mm}$ ) to which they were attached. Individual mats were demarcated with iron stakes. The transplanted and control mats were located $1 \mathrm{~m}$ above MLTL. 
The experiment started on November 3, 2003 (spring). After $45 \mathrm{~d}$, the transplanted and control mats were collected and their dry weight measured as explained above. Three models can be proposed to explain patterns of difference in the biomass of Ulva lactuca mats in zones with and without Corallina officinalis: (1) because $C$. officinalis affects U. lactuca mats (our hypothesis), (2) mats are different between zones but not because of zone characteristics, and (3) a combination of both (see Crowe \& Underwood 1998, Underwood et al. 2004). Following Zar (1999), 2 separate 2-way ANOVAs were conducted to distinguish among models. In both analyses one of the factors was Treatment (fixed, 3 levels: unmanipulated, translocated, and transplanted); however, in one analysis the second factor was the original zone to which the mat belonged (thereafter 'Origin'), whereas in the other analysis the second factor was the zone in which the mat was at the end of the experiment (thereafter 'Destination') (see Underwood et al. 2004). Under Model 1 the analysis from the origin point of view will show interaction while that from the destination point of view will only show significant differences between destinations. This contrasts with predictions of Model 2 (only origin effect from the origin point of view and interaction from the destination point of view). Model 3 predicts interactions from both points of view (see Crow \& Underwood 1998, Underwood et al. 2004).

Effect of desiccation on Ulva lactuca mats growing above Corallina officinalis. Given that the previous experiment showed a negative effect of Corallina officinalis on the biomass of individual Ulva lactuca mats (see 'Results'), we conducted an experiment to evaluate the hypothesis that such an effect is caused by desiccation. The experiment consisted of 3 treatments (10 replicates each): (1) mats in which the turf and mat were removed as intact as possible in a $0.3 \mathrm{~m}^{2}$ area and substrate level was excavated to $0.1 \mathrm{~m}$ depth to allow water to form pools, before redeployment of the coralline turf and $U$. lactuca mats (RL treatment), (2) mats identical to (1) but without excavating to $0.1 \mathrm{~m}$ depth, thus redeployment without modification of the substrate level (RNL treatment; control for algae removal and relocation), and (3) mats in plots undisturbed ( $\mathrm{C}$ treatment; control). The experiment was started on December 21, 2003 (early summer) and, after $60 \mathrm{~d}$, mats were collected and their dry weight measured as explained above. The $H_{0}$ of no differences between treatments was evaluated with 1-way ANOVA (Zar 1999).

Surface topography in zones with and without Corallina officinalis. To evaluate the hypothesis that substrate topography is different in zones with and without Corallina officinalis, a $0.5 \mathrm{~m}$ long metal ruler was randomly deployed in zones with $(\mathrm{n}=13)$ and without $(\mathrm{n}=11)$ coralline turf. The number of contacts between the ruler and the substrata surface (of coralline turf or sediment), the length of each contact, and the maximal vertical distance between the ruler and the substrata surface (between contacts) were measured. Each of those variables was considered to reflect substrate complexity. Thus, flat substrata would have few large contacts with little distance between the ruler and the substrata surface, while complex surfaces would have larger numbers of small contacts and a greater distance between the ruler and the substrata surface. Although there are indexes to characterize surface topography (e.g. Beck 1998, Hills et al. 1999, Commito \& Rusignuolo 2000), we used this simple method because it better allowed us to evaluate changes in surface relief due to the presence of coralline algae (compared to empty flat zones). The $H_{0}$ of no difference in the variables measured between zones with and without coralline turf were analyzed with $t$-tests (Zar 1999).

Effect of Corallina officinalis surface topography on Ulva lactuca. To evaluate the hypothesis that the effect of Corallina officinalis on Ulva lactuca is related to the topography of $C$. officinalis turf, experiments with coralline surface mimics were performed on January 28, 2004 (summer). Square surface mimics (0.5 m side length, $0.1 \mathrm{~m}$ height) were built with fast bonding foam (1-component polyurethane foam, moisture curing) from negative molds obtained in the field using the same product. Mimics were attached to paving tiles $\left(0.5 \mathrm{~m}^{2}\right)$ to prevent flotation. The experimental design consisted of 3 treatments with 13 replicates each: (1) U. lactuca transplanted to zones without $C$. officinalis (W), (2) U. lactuca transplanted to zones with $C$. officinalis (C), and (3) U. lactuca transplanted to mimics surfaces of C. officinalis (CM). All mats used for this experiment were randomly taken from zones without $C$. officinalis. After $45 \mathrm{~d}$, mats were collected and their dry weight was measured. The $H_{0}$ of no difference in dry weight of $U$. lactuca mats between treatments was evaluated with ANOVA (Zar 1999). Bonferroni corrections were made in the pairwise comparisons described in this and previous sections (see Rice 1989).

\section{RESULTS}

\section{Patterns of distribution of Ulva lactuca}

Results of factorial ANOVA indicated that Ulva lactuca cover varies between zones with and without Corallina officinalis, depending on the intertidal level (i.e. C. officinalis $\times$ Tidal level interaction; Table 1). Main effects of presence/absence of $C$. officinalis and tidal level were not considered since the significant 
Table 1. Results of factorial ANOVA showing effect of presence/absence of Corallina officinalis, tidal level, and interaction between the 2 factors on the cover of Ulva lactuca

\begin{tabular}{|lrrrc|}
\hline Source & df & MS & \multicolumn{1}{c|}{$F$} & $\mathrm{p}$ \\
\hline C. officinalis & 1 & 76782.27 & 21.46 & $<0.001$ \\
Tidal level & 10 & 8519.27 & 2.38 & 0.09 \\
C. officinalis $\times$ Tidal level & 10 & 3567.27 & 11.02 & $<0.001$ \\
Transect (C. officinalis) & 18 & 407.53 & 1.26 & 0.2 \\
Error & 198 & 383.03 & & \\
\hline
\end{tabular}

interaction between these factors indicates that they are not independent (see Underwood 1997). At the level of the height on the shore where $C$. officinalis patches are found (i.e. 0.3 to $2.1 \mathrm{~m}$ height from the MLTL), the cover of U. lactuca was less in zones with C. officinalis (Fig. 1). There were no differences in $U$. lactuca cover between the zones with and without $C$. officinalis at tidal levels where $C$. officinalis were not present (i.e. 0 to 0.3 and 2.1 to $2.7 \mathrm{~m}$ above MLTL, respectively; Fig. 1).

There was no difference in the number of mats of Ulva lactuca between zones with and without coralline turf $\left(X_{\text {without }}=21.67\right.$ mats per sample station, $\mathrm{SD}=5.91$; $X_{\text {with }}=20.33$ mats per sample station, $\mathrm{SD}=8.78$; $t=$ 0.488 , df $=28, \mathrm{p}>0.1$ ). However, the dry weight of mats of $U$. lactuca was greater in zones without Corallina officinalis $\left(X_{\text {without }}=2.8 \mathrm{~g}, \mathrm{SD}=1.09 ; X_{\text {with }}=0.65 \mathrm{~g}\right.$, $\mathrm{SD}=0.39$; $\log$ transformation; $t=11.27$, df $=44, \mathrm{p}<$ $0.001)$.

\section{Effect of Corallina officinalis on the biomass of individual Ulva lactuca mats}

From the origin point of view, there was a significant Interaction effect (log transformed data, $F_{2,48}=36.43$, $\mathrm{p}<0.001$; Fig. 2A) while from the destination point of view there was only a significant Destination effect

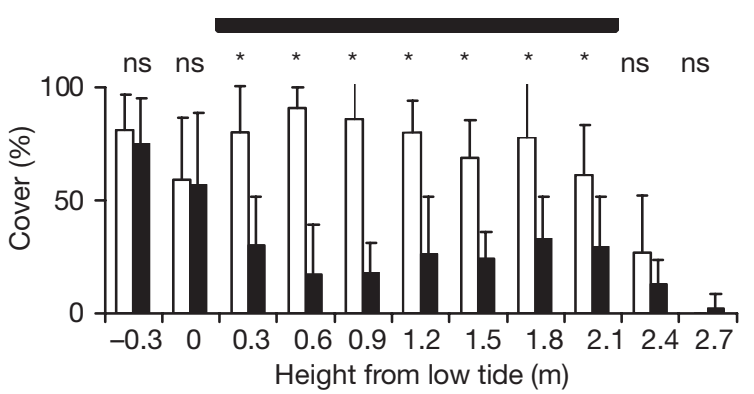

Fig. 1. Ulva lactuca. Percentage cover at different tidal levels in nearby areas with (black bars) and without (white bars) Corallina officinalis. Black bar above the graph shows tidal levels at which $C$. officinalis was found. In all figures bars show means + SD. *: significant differences $(p<0.05)$

between zones at same tidal level $;$ ns $=$ not significant

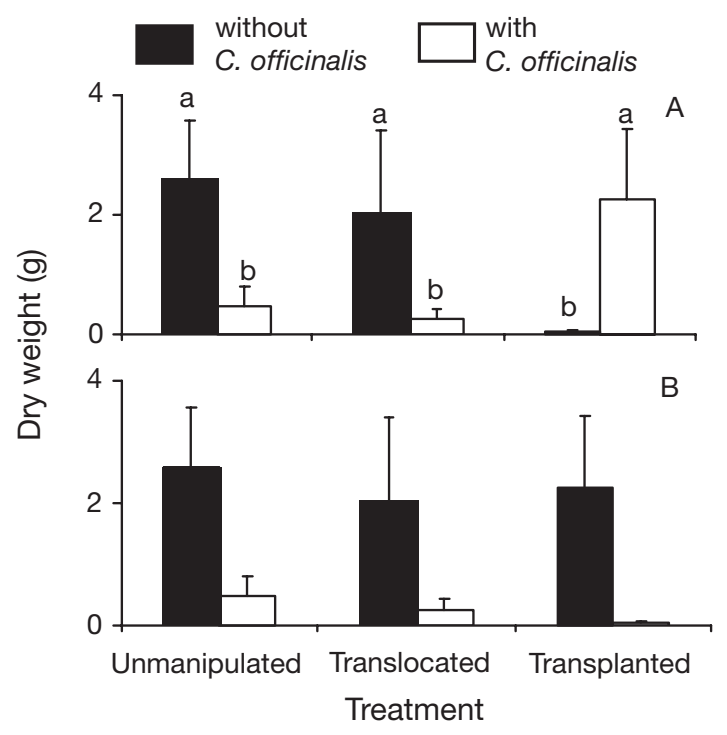

Fig. 2. Ulva lactuca. Dry weight of mats after $45 \mathrm{~d}$ transplant experiment. (A) Origin point of view; (B) destination point of view. a, b: significant differences

(log transformed data, $\left.F_{1,48}=78.44, \mathrm{p}<0.001\right)$ but no Treatment (log transformed data, $F_{2,48}=1.24, \mathrm{p}=0.29$ ) nor Interaction $\left(F_{2,48}=0.32\right)$ effect (Fig. $\left.2 B\right)$ on the dry weight of Ulva lactuca mats.

\section{Effect of desiccation on Ulva lactuca mats growing above Corallina officinalis}

At the end of the experiment, mats from treatments within the Corallina officinalis zones with the surface lowered showed greater dry weight than mats from controls (log transformation; $F_{2,27}=7.59, \mathrm{p}<0.005$; Fig. 3A).

\section{Surface topography in zones with and without Corallina officinalis}

The number of contacts between the ruler and the surface was higher $(t=4.84, \mathrm{df}=22, \mathrm{p}<0.01)$, the mean length of the contacts in $0.5 \mathrm{~m}$ was less (log transformation; $t=12.26$, df $=22, \mathrm{p}<0.001)$, and mean maximal distances between the ruler and the surface were greater $(t=6.74$, df $=22, \mathrm{p}<0.001)$ in zones with coralline turf than without turf.

\section{Effect of Corallina officinalis surface topography on Ulva lactuca}

At the end of the experiment, the dry weights of Ulva lactuca mats from the treatments with Corallina officinalis (C) and with mimics of $C$. officinalis (CM) were lower than mats from treatments without $C$. officinalis (log transformation; $F_{2,36}=50.11, \mathrm{p}<0.001$; Fig. 3B). 
There was no difference in dry weight between mats transplanted to real C. officinalis turf and mats transplanted to turf mimics (Tukey's HSD test post ANOVA).

\section{DISCUSSION}

The percentage cover of Ulva lactuca was less inside Corallina officinalis patches. In zones with C. officinalis, cover of $U$. lactuca was higher in the high subtidal (sample station $1 ;-0.3 \mathrm{~m}$ from low tide) and the low intertidal than in the mid and high intertidal. This pattern contrasted with the distribution pattern of $C$. officinalis and is the reverse to the pattern described for coralline turf-forming algae elsewhere (i.e. Sydney, Australia; Coleman 2003), where corallines are more abundant in the subtidal and their epiphytes in the intertidal. Coralline species are known to prevent overgrowing by fleshly algae using different mechanisms including synthesis of antifouling compounds (Kim et al. 2004), creation of refuge for herbivores that control epiphytes (Paine 1980, Steneck 1982), and thallus shedding (Johnson \& Mann 1986). In addition, it has been suggested that the microtopography of the coralline surface can prevent epiphyte recruitment by exposing germlings to mechanical dislodgement (Figueiredo et al. 1997). However, no single process appeared to be important in this study system.

Less Ulva lactuca cover inside coralline patches was not a consequence of a less mat density but a consequence of smaller mat sizes (measured as dry weight). Experimental evaluation of the effect of Corallina officinalis on $U$. lactuca showed that the differences in mat dry weight between zones (with and without $C$. officinalis) reflected a property of the zones (i.e. the presence of $C$. officinalis affects U. lactuca). Although the experimental design lacked a manipulation control (manipulation of mats before placing them back in their original position), which impeded us from distinguishing between the effect of moving organisms to a strange site and the effect of disturbing them (see Chapman 1986, Crow \& Underwood 1998, Honkoop et al. 2003, Underwood et al. 2004), translocation treatment allowed evaluation of the net effect. This design, although not ideal (see Crow \& Underwood 1998, Honkoop et al. 2003, Underwood et al. 2004), is still useful to evaluate our hypothesis. In coralline turfs and crusts, the presence of herbivores that graze and limit epiphytes is well known (Paine 1980, Steneck 1982, Karez et al. 2004), and the hypothetical presence of a grazer in $C$. officinalis turf can explain observed patterns and experiment results. Nevertheless, U. lactuca regenerated their fronds when transplanted to $C$. officinalis patches where surface level was lowered to allow the permanence of pools during low tide. This

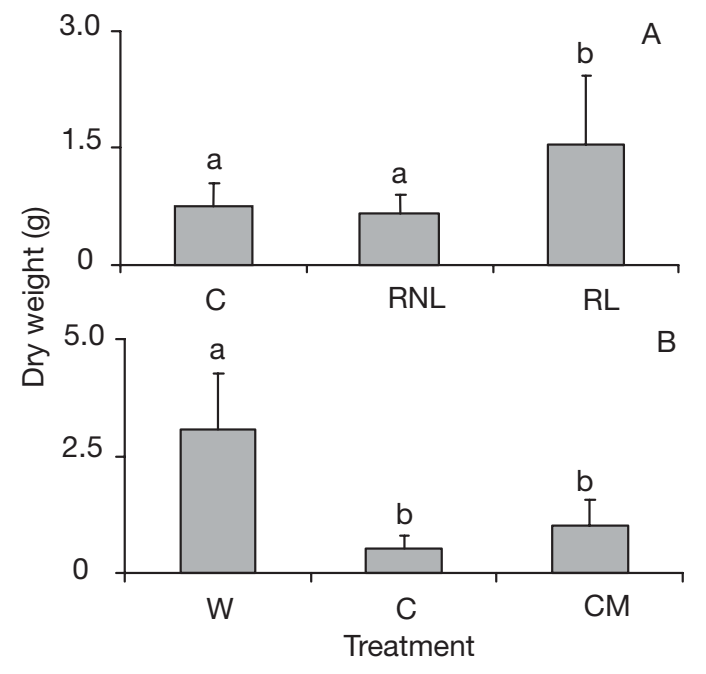

Fig. 3. Ulva lactuca. (A) Dry weight of mats after $60 \mathrm{~d}$ transplant experiment to evaluate effect of desiccation. C: mats from plots with Corallina officinalis kept undisturbed; RNL: mats from plots where algal turf was removed and reimplanted; RL: mats from plots where algal turf was removed and substrate lowered by $0.1 \mathrm{~m}$ before turf reimplantation. (B) Dry weight of mats after $45 \mathrm{~d}$ transplant experiment to evaluate effect of surface topography; W: mats transplanted to plots without Corallina officinalis; C: to plots with C. officinalis; $\mathrm{CM}$ : to plots with mimics of $C$. officinalis; a, b: significant differences ( $p<0.05$, Tukey test after ANOVA)

indicated that desiccation is a primary cause of decreases in $U$. lactuca mat size.

Experimental evaluation of the effect of topography of Corallina officinalis showed that coralline turf mimics also have negative effects on Ulva lactuca mat size, which suggested that surface topography is causing this effect. The mimic experiment lacked adequate controls for artifacts associated with the manipulation of $U$. lactuca mats (there was neither an unmanipulated treatment nor a disturbance control, see Chapman 1986), which limited the interpretation and extrapolation to the real situation. Nevertheless, the absence of effects of translocation in the reciprocal transplant experiment may have indicated that there is not an artifact associated with manipulation procedure, and that observed effects can be interpreted as a result of differences in surface topography of treatments rather than as artifact effects. Dry weight of mats after transplantation to natural coralline turf was not different to that of mats transplanted to turf mimics. However, we observed a trend that the dry weight of mats from real coralline turf was reduced compared to that of mats transplanted to turf mimics (see Fig. 3B), which indicated that another process may also be influencing this interaction.

Desiccation is known to be one of the most important abiotic factors that influences species distribution and community structure in intertidal habitats. Several models describe that the upper limit of distribution of 
intertidal species is often determined by tolerance to desiccation (Johnson et al. 1998, Bertness 1999). Lack of water entails not only an increased exposure to high temperatures and loss of internal water but also an increased exposure to solar radiation that can inhibit growth and damage tissues (Huppertz et al. 1990, Bischof et al. 2002). Although it probably traps water inside its matrix, Corallina officinalis may increase desiccation stress at the surface. This effect may be because the surface of $C$. officinalis turf amplifies the roughness of the substrate, producing more and deeper irregularities as it grows. The Patagonian climate is characterized by constant and often intense winds and low humidity (Paruelo et al. 1998). These conditions increase evaporation, and are likely to interact with the roughness contributed by coralline turf to generate a habitat for epiphytes that is more exposed to wind desiccation.

Increasing terrestrial discharge of nutrients into coastal waters and the subsequent increase in the cover of fleshly fast growing algae (Raffaelli et al. 1998) can generate large changes in intertidal community structure (Menge 1992, Valiela et al. 1997). One of the major effects of eutrophication on estuarine habitats is the periodic and massive cover of intertidals by fast growing ephemeral algae (Rosenberg 1985) that are efficient in $\mathrm{N}$ uptake (Carpenter 1990). Canopies of those algae can negatively affect the previously dominant species (Hauxwell et al. 2001) and finally affect the whole community (Carpenter et al. 1985). Under high $\mathrm{N}$ supply, green fleshly algae, for example, have high growth rates and usually out-compete slow growing brown and red algae (Pedersen 1995, Pihl et al. 1999). The Patagonian coasts are not exceptions of this global process (Piriz et al. 2003), and waste waters generate local increases of Ulva spp. (Piriz et al. 2003). However, habitat modification by Corallina officinalis limits the development of $U$. lactuca mats, which may be important to maintain community integrity and species diversity, particularly when taking into account the importance of turf-forming algae in creating habitat for many organisms (Kelaher et al. 2003).

In extreme environments with strong abiotic forces, autogenic ecosystem engineers can have important influences on community structure (Jones et al. 1997, Bruno et al. 2003). This is not only because positive interactions are often very important in harsh environments (Bertness \& Leonard 1997, Hacker \& Gaines 1997), but also because the effect of ecosystem engineering on other species can be negative and even drive certain species to exclusion (see Connell 2003). An autogenic ecosystem engineer that has positive effects on many species, and generates extremely rich assemblages of invertebrates (see Kelaher 2002, Kelaher et al. 2003, 2004), can also negatively affect other species.
Acknowledgements. We thank the staff of the Instituto de Biología Marina y Pesca 'Alte. Storni' (San Antonio Oeste), particularly Dr. M. Narvarte, for allowing us the use of their facilities. We also thank Drs. M.L. Piriz and G. Casas for algal identification. This article benefited from the critical reading of Drs. J. Gutiérrez, B. Silliman and 2 anonymous referees. This project was partially supported by Universidad Nacional de Mar del Plata, CONICET and Fundación Antorchas (Grant 13900-13; all granted to O.I.). P.D., M.E. and J.A. were supported by fellowships from CONICET (Argentina).

\section{LITERATURE CITED}

Beck MW (1998) Comparison of the measurement and effects of habitat structure on gastropods in rocky intertidal and mangrove habitats. Mar Ecol Prog Ser 169:165-178

Bertness MD (1999) The ecology of Atlantic shorelines. Sinauer Associates, Sunderland, MA

Bertness MD, Leonard GH (1997) The role of positive interactions in communities: lessons from intertidal habitats. Ecology 78:1976-1986

Bischof K, Peralta G, Krabs G, van de Poll WH, Pérez-Lloréns JL, Breeman AM (2002) Effects of solar UV-B radiation on canopy structure of Ulva communities from southern Spain. J Exp Bot 53:2411-2421

Bruno JF, Stachowicz JJ, Bertness MD (2003) Inclusion of facilitation into ecological theory. Trends Ecol Evol 18: 119-125

Callaway RM, Brooker RW, Choler P, Kikvidze Z and 9 others (2002) Positive interactions among alpine plants increase with stress. Nature 417:844-848

Carpenter RC (1990) Competition among marine macroalgae: a physiological perspective. J Phycol 26:6-12

Carpenter SR, Kitchell JF, Hodgson JR (1985) Cascading trophic interactions and lake productivity. Bioscience 35: $634-639$

Chapman MG (1986) Assessment of some controls in experimental transplants of intertidal gastropods. J Exp Mar Biol Ecol 103:181- 201.

Coleman MA (2003) Effects of ephemeral algae on coralline recruits in intertidal and subtidal habitats. J Exp Mar Biol Ecol 282:67-84

Commito JA, Rusignuolo BR (2000) Structural complexity in mussel beds: the fractal geometry of surface topography. J Exp Mar Biol Ecol 255:133-152

Connell SD (2003) Negative effects overpower the positive of kelps to exclude invertebrates from the understory community. Oecologia 137:97-103

Crooks JA (2002) Characterizing ecosystem-level consequences of biological invasions: the role of ecosystem engineers. Oikos 97:153-166

Crowe TP, Underwood AJ (1998) Testing behavioural 'preference' for suitable microhabitats. J Exp Mar Biol Ecol 225: $1-11$

Dean RL, Connell JH (1987) Marine invertebrates in an algal succession. III. Mechanisms linking habitat complexity with diversity. J Exp Mar Biol Ecol 109:249-273

Dethier MN, Graham ES, Cohen S, Tear LM (1993) Visual versus random-point percent cover estimations: 'objective' is not always better. Mar Ecol Prog Ser 96:93-100

Downes BJ, Lake PS, Schreiber ESG, Glaister A (1998) Habitat structure and regulation of local species diversity in a stony, upland stream. Ecol Monogr 68:237-257

Figueiredo MA de O, Norton TA, Kain JM (1997) Settlement and survival of epiphytes on two intertidal crustose coralline alga. J Exp Mar Biol Ecol 213:247-260 
Fogel BN, Crain CM, Bertness MD (2004) Community level engineering effects of Triglochin maritime (seaside arrowgrass) in a saltmarsh in northern New England. J Ecol 92: 589-597

Gilinsky E (1984) The role of fish predation and spatial heterogeneity in determining benthic community structure. Ecology 65:455-468

Gutiérrez JL, Iribarne OO (2004) Conditional responses of organisms to habitat structure: an example from intertidal mudflats. Oecologia 139:572-582

Hacker SD, Gaines SD (1997) Some implications of direct positive interactions for community species diversity. Ecology 78:1990-2003

Hacker SD, Steneck RS (1990) Habitat architecture and the abundance and body-size-dependent habitat selection of a phytal-amphipod. Ecology 71:2269-2285

Hauxwell J, Cebrian J, Furlong C, Valiela I (2001) Macroalgal canopies contribute to eelgrass (Zostera marina) decline in temperate estuaries ecosystems. Ecology 82:1007-1022

Helbling EW, Barbieri ES, Sinha RP, Villafañe VE, Hader DP (2004) Dynamics of potentially protective compounds in Rhodophyta species from Patagonia (Argentina) exposed to solar radiation. J Photochem Photobiol B 75:63-71

Hills JM, Thomason JC, Muhl J (1999) Settlement of barnacle larvae is governed by Euclidean and non fractal surface characteristics. Funct Ecol 13:868-875

Honkoop PJC, Bayne BL, Underwood AJ, Svensson S (2003) Appropriate experimental design for transplanting mussels (Mytilus sp.) in analyses of environmental stress: an example in Sydney Harbour (Australia). J Exp Mar Biol Ecol 297:253-268

Huppertz K, Hanelt D, Nultsch W (1990) Photoinhibition of photosynthesis in the marine brown algae Fucus serratus as studied in field experiments. Mar Ecol Prog Ser 66:175-182

Johnson CR, Mann KH (1986) The crustose coralline alga, Phymatolithon Foslie, inhibits the overgrowth of seaweeds without relying on herbivores. J Exp Mar Biol Ecol 96: 127-146

Johnson MP, Hawkins SJ, Hartnoll RG, Norton TA (1998) The establishment of fucoid zonation on algal-dominated rocky shores: hypotheses derived from a simulation model. Funct Ecol 12:259-269

Jones CG, Lawton JH, Shachak M (1994) Organisms as ecosystem engineers. Oikos 69:373-386

Jones CG, Lawton JH, Shachak M (1997) Positive and negative effects of organisms as physical ecosystem engineers. Ecology 78:1946-1957

Karez R, Engelbert S, Kraufuelin P, Pedersen MF, Sommer J (2004) Biomass response and changes in composition of ephemeral macroalgal assemblages along an experimental gradient of nutrient enrichment. Aquat Bot 78:103-117

Kelaher BP (2002) Influence of physical characteristics of coralline turf on associated macrofaunal assemblages. Mar Ecol Prog Ser 232:141-148

Kelaher BP (2003) Changes in habitat complexity negatively affect diverse gastropod assemblages in coralline algal turf. Oecologia 145:431-441

Kelaher BP, Underwood AJ, Chapman MG (2003) Experimental transplantations of coralline algal turf to de-

Editorial responsibility: Antony J. Underwood (Contributing Editor), Sydney, NSW, Australia monstrate causes of differences in macrofauna at different tidal heights. J Exp Mar Biol Ecol 282:23-41

Kelaher BP, Castilla JC, Seed R (2004) Intercontinental test of generality for spatial patterns among diverse molluscan assemblages in coralline algal turf. Mar Ecol Prog Ser 271: 221-231

Kim MJ, Chai JS, Kang SE, Cho JY, Jin HJ, Chun BS, Hong YK (2004) Multiple allelopathic activity of the crustose coralline alga Lithophyllum yessoense against settlement and germination of seaweed spores. J Appl Phycol 16: 175-179

MacArthur RH, MacArthur JW (1961) On bird species diversity. Ecology 42:594-598

Menge BA (1992) Community regulation: under what conditions are bottom-up factors important in rocky shores? Ecology 73:755-765

Morrison RIG, Ross RK (1989) Atlas of Neartic shorebirds of the coast of South America. Can Wildl Ser Spec Publ 2: 131-323

Murdoch WW, Evans FC, Peterson CH (1972) Diversity and patterns in plants and insects. Ecology 53:819-828

Paine RT (1980) Food webs: linkage, interaction strength and community infrastructure. J Anim Ecol 49:667-685

Paruelo JM, Beltrán A, Jobbágy, Sala O, Golluscio RA (1998) The climate of Patagonia: general patterns and controls of biotic processes. Ecol Aust 8:85-101

Pedersen MF (1995) Nitrogen limitation of photosynthesis and growth: comparison across aquatic plant communities in a Danish estuary (Roskilde fjord). Ophelia 41:261-272

Pihl L, Svenson A, Moksnes PO, Wennhage H (1999) Distribution of green algal mats throughout shallow soft bottoms of the Swedish Skagerrak archipelago in relation to nutrient sources and wave exposure. J Sea Res 41:281.294

Piriz ML, Eyras MC, Rostagno CM (2003) Changes in biomass and botanical composition of beach-cast seaweeds in a disturbed coastal area from Argentine Patagonia. J Appl Phycol 15:67-74

Raffaelli DG, Raven JA, Poole LJ (1998) Ecological impact of green macroalgal blooms. Oceanogr Mar Biol Annu Rev $36: 97-125$

Rice WR (1989) Analyzing tables of statistical tests. Evolution 43:223-225

Rosenberg R (1985) Eutrophication - the future marine coastal nuisance? Mar Pollut Bull 16:227-231

Steneck RS (1982) A limpet-coralline alga association: adaptations and defenses between a selective herbivore and its prey. Ecology 63:507-522

Underwood AJ (1997) Experiments in ecology: their logical design and interpretation using analysis of variance. Cambridge University Press, Cambridge

Underwood AJ, Chapman MG, Crowe TP (2004) Identifying and understanding ecological preferences for habitat or prey. J Exp Mar Biol Ecol 300:161-187

Valiela I, McClelland J, Hauxwell J, Behr PJ, Hersh D, Foreman K (1997) Macroalgal blooms in shallow estuaries: controls and ecophysiological and ecosystem consequences. Limnol Oceanogr 42:1105-1118

Zar JH (1999) Biostatistical analysis, 4th edn. Prentice Hall, Upper Saddle River, NJ

Submitted: May 17, 2005; Accepted: November 16, 2005

Proofs received from author(s): May 10, 2006 